\title{
Myxosporidian parasites of the genus Thelohanellus from different freshwater fishes of Washim, Maharashtra region
}

\author{
JR Somatkar and D. S. Dabhade \\ Post Graduate and Research Department of Zoology, R. A. Arts, Shri M. K. Commerce and Shri S. R. Rathi \\ Science Mahavidhyalaya, Washim. 444505 MS India
}

\begin{abstract}
The present work has been undertaken to study the Myxozoan parasites found in freshwater fishes. Myxozoan parasites were isolated from freshwater fishes collected from various water resources in the Washim region of Maharashtra, India. The Myxozoan parasites reported during the present study include Thelohanellus imphalensis, Thelohanellus anilae, Thelohanellus dykovi, Thelohanellus deri and Thelohanellus caudatus. These Myxozoan parasites have been recorded with heavy infection on gill and the kidney tissues of freshwater fishes with formation of plasmodial structure. The data of the present study indicates the presence of Thelohanellus parasites on gill surface and kidney of freshwater fishes mainly the Indian major carps in greater population which results in debilitary effect on the host. Based on the present study we suggest that controlling measures should be taken to interrupt the steps of parasitic transmission from one host to other. Emphasis should be given to control the parasite with a view to increase the protein production together with the rapid growth of fishes. Therefore extensive study should be carried out on the Myxozoan parasites otherwise: the pathogenecity caused by them by damaging the tissue and decreasing the nutritional value, will lower the productivity of fish. The main principle of fish disease control should be based on all round prophylaxis and prevention is better than treatment approach as treatment in such water bodies become impractical and uneconomic.
\end{abstract}

KEY WORDS: MYXOSPORIDIA, THELOHANELLUS, WASHIM, FRESHWATER FISHES

\section{INTRODUCTION}

Members of the phylum Myxozoa cause some of the most common and important parasitic diseases of fishes. Several species are known to cause serious losses in pisiculture. Infection with the disease myxosporidiasis typically appear as macroscopic white or yellowish cysts on body surface, gills, musculature. Species of Thelohanellus Kudo, 1933 are typically histozoic, tear shaped or pyriform to broadly ellipsoidal in valvular view and more slender in sutural view with single polar capsule (Lom and Dykova, 2006).

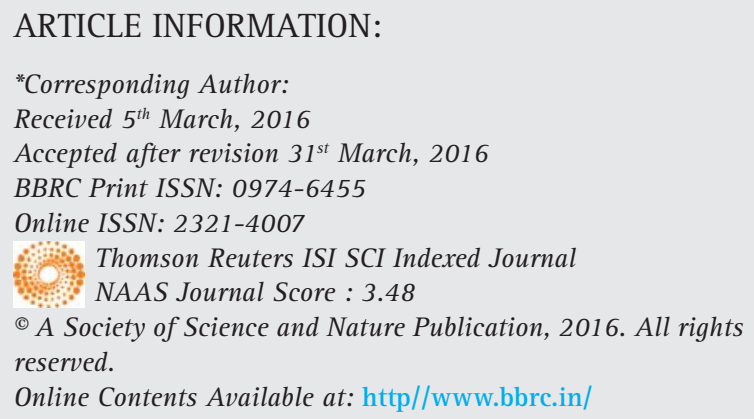


Many species of this genus have been recorded from various fishes in diverse localities of the world. Lom and Dykova(2006) enlisted as many as 39 species of Thelohanellus. Basu et al.,(2006) provided a synopsis of 32 Indian species belonging to the genus Thelohaellus including one new species, $T$. disporomorphus infecting Indian major carp Cirrhina mrigala. Kalavati and Nandi (2007) gave a compilation of 27 species of genus Thelohanellus infecting Indian fishes. Kaur and Singh (2012a.b.c.d, 2013) reported 17 species of Thelohanellus from Wetlands of Punjab with record of 10 new species. Recently Kaur et al., (2014a.b) added two more new species T. filli and T. dykovi from freshwater fishes of Punjab.

The present work recorded 5 known species of Thelohanellus viz, T. imphalensis (Hemananda et. al., 2010), T. anilae (Hemananda et al., 2010), T. dykovi (Kaur et. al., 2014), T. deri (Singh and Kaur, 2012) and T. caudatus (Pagarkar and Das, 1993) from freshwater fishes. The myxosporidian parasites of the genus Thelohanellus have negligible record from Maharashtra, India and the present research is the first contribution of the species Thelohanellus from Washim in Maharashtra state of India.The present research work has been undertaken to study one of the disease causing agent i.e. Myxozoan parasites from freshwater fishes in regard to obtain the healthy fish population by providing protective measures against parasites.

\section{MATERIAL AND METHODS}

The host fishes for the present study were collected from various dams and local fish market from 2010 to 2014. The collected fishes were brought to laboratory for necropsy procedure for examination of Myxozoan parasites. As such when cysts or abnormalities in the organs were noticed, myxozoans were suspected. For temporary mounting of parasites, fresh saline wet mounts were prepared. Fresh spores were mounted in Lugol's solution for presence of iodinophilous vacuoles in sporoplasm and Indian ink for presence of mucous coat around the spore. Extrusion of polar filament was achieved by treatment of fresh spores with 10\% KOH. For permanent preparation, a smear using fresh spores was prepared and allowed to air dry. Then these spores were fixed in 10\% buffered formalin and stained in Giemsa's stain (Cone and Anderson, 1977) and mounted in DPX.

Examinations of preparations were made under Olympus phase-contrast microscope at 100x magnification and The photographs of the slide were taken with the digital camera and drawing were made with Camera Lucida to illustrate the structure of spore. Measurements of spores were taken in micrometer with the aid of calibrated ocular micrometer.

\section{RESULTS AND DISCUSSION}

The various Myxozoan parasites of the genus Thelohanellus reported during the present study are described as under:

1. Thelohanellus imphalensis (Hemananda et. al., 2010)

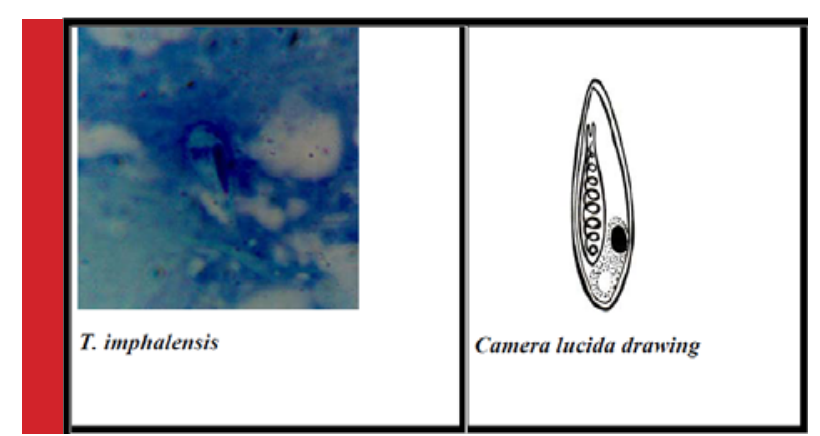

Taxonomic Summary

Type host : Labeo rohita

Parasite : : Thelohanellus imphalensis

Type locality : Ekburgii dam, Washim, Maharashtra

Site of : Gills

infection

Holotype : In slide no. M25a/2013, deposited in P.G. and Research department of Zoology, R.A. College, Washim Dist. Washim Maharashtra.

\section{Spore Description:}

1. Mature spores are histozoic and pyriform in shape.

2. The anterior end is tapering while the posterior end is broadly rounded.

3. The spore valves are moderately thick, smooth and the sutural line is indistinct.

4. No mucus envelope is observed around the spore body.

5. A single pyriform-polar capsule is present inside the spore body which is always located closer to one side of the wall at the central region of the spore.

6. At its anterior end the polar capsule is clearly bifurcated (a unique character among Thelohanellus spp.);

7. Inside the polar capsule the polar filament makes 6 - 8 coils.

8. The posterior part of the spore (extra capsular space) is filled with granular homogenous sporoplasm.

9. Inside the sporoplasm a single iodinophilous vacuole and single nucleus are present. 
10. The nucleus of the sporoplasm is bigger than the iodinophilous vacuole. The sporoplasm is oval in shape, situated towards the basal periphery of the polar capsule and upper portion reaches one third of the polar capsule.

\section{Reported by:}

Hemananda et al., (2010) from West Bengal.

\section{Remarks (Refer table 1)}

The first report of myxozoan parasite of the genus $T$. imphalensis was given by Hemananda et al., (2010) from gills of the cyprinid fish Labeo rohita Hamilton, 1822 collected from Manipur, India. The species is characterised by the presence of a bifurcated tip of polar capsule and an oval sporoplasm, whose upper portion reaches one third of the polar capsule from the basal side. Thelohanellus species reported in the present study have identical features with T. imphalensis (Hemananda et al., 2010). Hence the given species is identified as $T$. imphalensis (Hemananda et al., 2010).

Table 1: Morphometric comparision of $T$.

imphalensis obtained in the present study with those of (Hemananda et al., 2010).

\begin{tabular}{|l|l|l|}
\hline Character & $\begin{array}{l}\text { Thelohanellus } \\
\text { imphalensis }\end{array}$ & $\begin{array}{l}\text { Thelohanellus } \\
\text { imphalensis }\end{array}$ \\
\hline $\begin{array}{l}\text { Length of Spore } \\
(\mu \mathrm{m})\end{array}$ & $20.4-22.1$ & $20.0-21.4$ \\
\hline $\begin{array}{l}\text { Width of Spore } \\
(\mu \mathrm{m})\end{array}$ & $8.5-10.2$ & $8.2-10.0$ \\
\hline $\begin{array}{l}\text { Length of polar } \\
\text { capsule }\end{array}$ & $10.2-11.05$ & $10.1-1.9$ \\
\hline $\begin{array}{l}\text { Width of polar } \\
\text { capsule }\end{array}$ & $3.4-4.25$ & $3.2-4.1$ \\
\hline $\begin{array}{l}\text { No. of polar } \\
\text { filament coils }\end{array}$ & $7-8$ & $6-8$ \\
\hline & $\begin{array}{l}\text { Hemananda et al., } \\
(2010)\end{array}$ & Present study \\
\hline Locality & West Bengal & Maharashtra \\
\hline
\end{tabular}

2. Thelohanellus anilae (Hemananda et al., 2010)

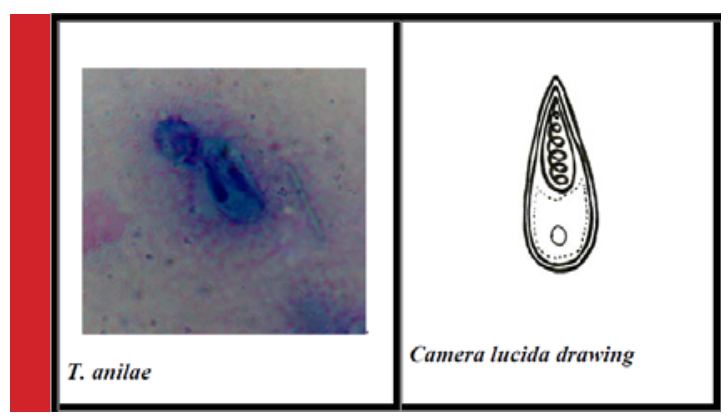

\section{Taxonomic Summary}

Type host : Labeo rohita

Parasite : Thelohanellus anilae

Type locality : Sonkhas dam, Washim, Maharashtra

Site of : Gills

infection

Holotype : In slide no. M29a/2013, deposited in P.G. and Research department of Zoology, R.A. College, Washim Dist. Washim Maharashtra.

\section{Spore Description:}

1. Two kinds of spores were found. They are distinctly different from each other. One spore is big, hence it is named macrospore and the other one is small and named microspore. Macrospores are approximately twice so big as microspores. Here described only the Microspore.

2. It is elongated pyriform with pointed anterior and rounded posterior end in valvular view.

3. The spore appears slightly lenticular in sutural view.

4. The sutural line is indistinct.

5. The spore valves are thin and smooth.

6. Polar capsule single, tear shaped with sharply pointed anterior and rounded posterior end.

7. It is anteriorly placed.

8. The coil of polar filament within the polar capsule is indistinct

9. The extra capsular region is occupied by homogenous sporoplasmic granules.

10. There is a small sporoplasmic nucleus inside the sporoplasm but iodinophilous vacuole absent.

Reported by Hemananda et al., (2010) from West Bengal.

\section{Remarks (Refer table 2)}

Hemananda et al., (2010) first time described Thelohanellus anilae from the gills of Labeo rohita from West Bengal. Two kinds of spores were found a macrospore and the other one microspore. Inside the polar capsule the polar filament makes 10-11 turns of coil occupying one third of the total spore body. The posterior part of the spore body is occupied by crescent-shaped sporoplasm with sporoplasmic granules. Inside the sporoplasm there is a small iodinophilous vacuole in some spores while the iodinophilous vacuole is indistinct in other spores without mucus envelope. The Thelohanellus species reported in the present study is identical in structural features and morphometry with $T$. anilae. So the species is identified as T. anilae (Hemananda et al., 2010). 


\begin{tabular}{|c|c|c|}
\hline Character & $\begin{array}{l}\text { Thelohanellus } \\
\text { anilae }\end{array}$ & $\begin{array}{l}\text { Thelohanellus } \\
\text { anilae }\end{array}$ \\
\hline $\begin{array}{l}\text { Length of Spore } \\
(\mu \mathrm{m})\end{array}$ & $12.75-13.6$ & 12.8 \\
\hline $\begin{array}{l}\text { Width of Spore } \\
(\mu \mathrm{m})\end{array}$ & 6.8 & 6.6 \\
\hline $\begin{array}{l}\text { Length of polar } \\
\text { capsule }(\mu \mathrm{m})\end{array}$ & 6.8-7.65 & 7.2 \\
\hline $\begin{array}{l}\text { Width of polar } \\
\text { capsule }(\mu \mathrm{m})\end{array}$ & $2.55-3.40$ & 2.9 \\
\hline \multirow[t]{2}{*}{$\begin{array}{l}\text { No. of polar } \\
\text { filament coils }\end{array}$} & & \\
\hline & $\begin{array}{l}\text { Hemananda } \\
\text { et. al. (2010) }\end{array}$ & Present study \\
\hline Locality & West Bengal & Maharashtra \\
\hline
\end{tabular}

\section{Thelohanellus dykovi (Kaur et. al., 2014)}

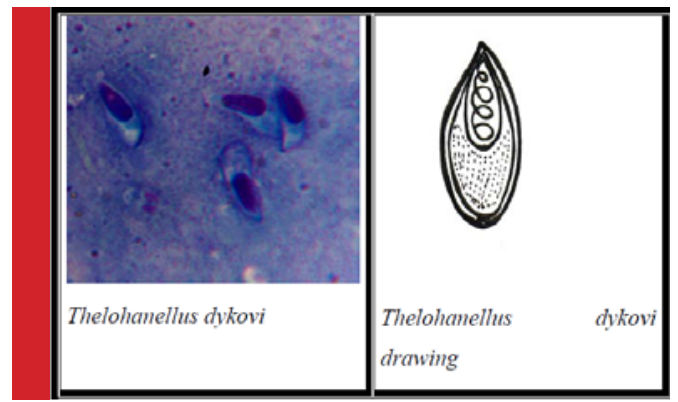

Taxonomic Summary

$$
\begin{array}{ll}
\text { Type host } & \text { : Labeo rohita } \\
\text { Parasite } & : \text { Thelohanellus dykovi } \\
\text { Type locality } & \text { : Supkhela dam, Washim, Maharashtra } \\
\text { Site of } & : \text { Gills } \\
\text { infection } & \\
\text { Holotype } & \text { :In slide no. M7b/2013, deposited } \\
& \text { in P.G. and Research department of } \\
& \text { Zoology, R.A. College, Washim Dist. } \\
& \text { Washim Maharashtra. }
\end{array}
$$

\section{Spore Description:}

1. Spores histozoic, elongated pyriform in valvular view,

2. Spores having tapering anterior end and rounded posterior end.

3. Shell valves thin, smooth and symmetrical.

4. Parietal folds absent.
5. Presence of a single Polar capsule which is elongated, pear shaped with distinct tubular neck and occupies one third of the total spore body cavity.

6. Polar filament form 18-20 coils, arranged perpendicular to the polar capsule axis.

7. Sporoplasm occupies whole of the extracapsular space behind the polar capsule and contain two sporoplasmic nuclei.

8. Iodinophilous vacuole is absent.

Reported by : Kaur et al.,(2014) from Punjab

\section{Remarks (Refer table 3)}

Thelohanellus dykovi was first reported by Kaur et al., (2014) infecting gills of cultured Indian major carp, Labeo rohita (Hamilton, 1822) from Punjab. Spores of $T$. dykovi (Kaur et al., 2014) were morphologically unique in having tapering anterior end and rounded posterior end measuring $10.74 \times 4.07 \mu \mathrm{m}$ in size. Shell valves were thin, $0.50 \mu \mathrm{m}$ in thickness, smooth and symmetrical. The Thelohanellus species reported in the present study have identical features with T. dykovi (Kaur et al., 2014). Hence the given species is identified as T. dykovi (Kaur et al., 2014) reported from Labeo rohita fish.

Table 3: Morphometric comparision of $T$ dykovi obtained in the present study with those of Kaur et al., (2014)

\begin{tabular}{|l|l|l|}
\hline Characters & $\begin{array}{l}\text { Thelohanellus } \\
\text { dykovi }\end{array}$ & $\begin{array}{l}\text { Thelohanellus } \\
\text { dykovi }\end{array}$ \\
\hline Length of Spore $(\mu \mathrm{m})$ & $9.74-11.74$ & $10.6-11.7$ \\
\hline Width of Spore $(\mu \mathrm{m})$ & $3.10-5.03$ & $4.3-5.2$ \\
\hline $\begin{array}{l}\text { Length of polar capsule } \\
(\mu \mathrm{m})\end{array}$ & $4.58-8.38$ & $7.4-8.3$ \\
\hline $\begin{array}{l}\text { Width of polar capsule } \\
(\mu \mathrm{m})\end{array}$ & $1.04-3.04$ & $2.1-2.9$ \\
\hline $\begin{array}{l}\text { No. of polar filament } \\
\text { coils }\end{array}$ & $18-20$ & $18-20$ \\
\hline & Kaur et al. $(2014)$ & Present study \\
\hline Locality & Punjab & Maharashtra \\
\hline
\end{tabular}

4. Thelohanellus deri (Singh and Kaur, 2012)

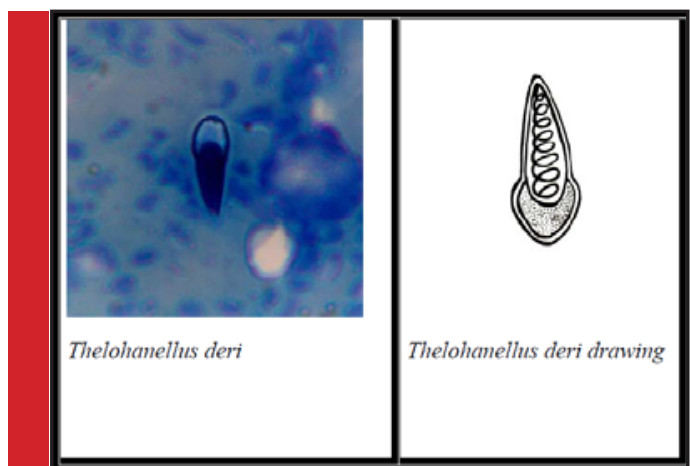


Taxonomic Summary

Type host : Labeo rohita

Parasite : Thelohanellus deri

Type locality : Kajalamba dam, Washim, Maharashtra

Site of : Gills

infection

Holotype :In slide no. M26a/2013, deposited in P.G. and Research department of Zoology, R.A. College, Washim Dist. Washim Maharashtra.

\section{Spores description}

1. The spores are histozoic, elongateled and pyriform in valvular view having sharply pointed anterior end and broad rounded, bulb-like posterior end demarcated by a small constriction located medioposteriorly.

2. Shell valves are thin, smooth, symmetrical.

3. Parietal folds are absent.

4. Polar capsule broadly pyriform with sharply pointed anterior end and broad rounded posterior end and is situated anteriorly in the spore body cavity.

5. It occupies more than half of the spore body cavity.

6. Polar capsule contains 6-7 coils of polar filament arranged obliquely to the polar capsule axis.

7. Two capsulogenic nuclei are present beneath the polar capsule.

8. Sporoplasm is agranular, homogenous and occupies whole of the extracapsular space behind the polar capsule.

9. Sporoplasm contain two sporoplasmic nuclei.

10. An iodinophilous vacuole is absent

Reported by Singh and Kaur (2012) from Punjab.

\section{Remarks (Refer table 4)}

Thelohanellus deri was first reported by Singh and Kaur (2012) from Labeo dero from Ropar Wetland, Punjab. Spores of T.deri (Singh and Kaur, 2012) were broadly pyriform with sharply pointed anterior end and broad rounded posterior end and is situated anteriorly in the spore body cavity. It occupy more than half of the spore body cavity and contain 6-7 coils of polar filament arranged obliquely to the polar capsule axis. Thelohanellus species reported in the present study have identical features with T. deri (Singh and Kaur, 2012). Hence the given species is identified as T. deri (Singh and Kaur, 2012).
Table 4: Morphometric comparision of $T$. deri obtained in the present study with those of (Singh and Kaur, 2012).

\begin{tabular}{|l|l|l|}
\hline Character & $\begin{array}{l}\text { Thelohanellus } \\
\text { deri }\end{array}$ & $\begin{array}{l}\text { Thelohanellus } \\
\text { deri }\end{array}$ \\
\hline $\begin{array}{l}\text { Length of Spore } \\
(\mu \mathrm{m})\end{array}$ & $9.5-10.5$ & $9.8-10.3$ \\
\hline $\begin{array}{l}\text { Width of Spore } \\
(\mu \mathrm{m})\end{array}$ & $4.7-5.3$ & $4.9-5.2$ \\
\hline $\begin{array}{l}\text { Length of polar } \\
\text { capsule }\end{array}$ & $5.0-5.9$ & $5.1-5.6$ \\
\hline $\begin{array}{l}\text { Width of polar } \\
\text { capsule }\end{array}$ & $3.0-4.2$ & $3.2-3.7$ \\
\hline $\begin{array}{l}\text { No. of polar } \\
\text { filament coils }\end{array}$ & $6-7$ & $5-7$ \\
\hline & $\begin{array}{l}\text { Singh and Kaur } \\
(2012)\end{array}$ & Present study \\
\hline Locality & Punjab. & Maharashtra \\
\hline
\end{tabular}

5. Thelohanellus caudatus (Pagarkar and Das, 1993)

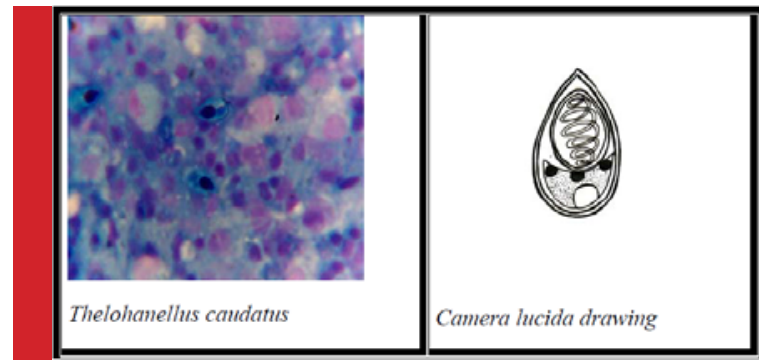

Taxonomic Summary

Type host : Catla catla

Parasite : Thelohanellus caudatus

Type locality : Tornala dam, Washim, Maharashtra

Site of : : Gills

infection

Holotype :In slide no. M30 a/2013, deposited in P.G. and Research department of Zoology, R.A. College, Washim Dist. Washim Maharashtra.

\section{Plasmodia.}

Small, white, spherical to round. each plasmodium contained 12-13 spores.

\section{Spores}

1. Spores were histozoic, pyriform in valvular view.

2. Spore shows tapering and pointed anterior ends and broad rounded posterior ends.

3. The sutural ridge was distinct and straight. 
4. Shell valves were thin, smooth and symmetrical.

5. Parietal folds were absent.

6. Polar capsules were oval, with blunt anterior ends and rounded posterior ends.

7. The polar filament formed 5-6 coils and was arranged obliquely to the polar capsule axis.

8. Sporoplasms occupied all extracapsular space behind polar capsules, and contained three sporoplasmic nuclei.

9. An iodinophilous vacuole present.

Reported by Pagarkar and Das (1993) from West Bengal and Singh and Kaur (2012) from Punjab

\section{Remarks (Refer table 5)}

T. caudatus was first described by Pagarkar and Das (1993) in Labeo rohita from West Bengal with oval shape, thick shell valves. A polar capsule is present with pyriform shape situated in anterior half of spore. The sporoplasm occupies the posterior half with two nuclei very close to each other with iodinophilous vacuoles. The Thelohanellus species reported in the present study is identical with T.caudatus (Pagarkar and Das, 1993) hence the present species has been identified as $T$. caudatus (Pagarkar and Das, 1993).

Table 5: Morphometric comparision of $T$. imphalensis obtained in the present study with those of Pagarkar and Das (1993) and Singh and Kaur (2012).

\begin{tabular}{|l|l|l|l|}
\hline Character & $\begin{array}{l}\text { Thelohanellus } \\
\text { caudatus }\end{array}$ & $\begin{array}{l}\text { Thelohanellus } \\
\text { caudatus }\end{array}$ & $\begin{array}{l}\text { Thelohanellus } \\
\text { caudatus }\end{array}$ \\
\hline $\begin{array}{l}\text { Length of } \\
\text { Spore }(\mu \mathrm{m})\end{array}$ & $13-14$ & 15.0 & 14.9 \\
\hline $\begin{array}{l}\text { Width of } \\
\text { Spore }(\mu \mathrm{m})\end{array}$ & $8.5-9.5$ & 7.0 & 6.9 \\
\hline $\begin{array}{l}\text { Length } \\
\text { of polar } \\
\text { capsule }(\mu \mathrm{m})\end{array}$ & $7.0-7.5$ & 6.3 & 6.2 \\
\hline $\begin{array}{l}\text { Width } \\
\text { of polar } \\
\text { capsule }(\mu \mathrm{m})\end{array}$ & $5.0-5.5$ & 4.6 & 3.0 \\
\hline & $\begin{array}{l}\text { Pagarkar and } \\
\text { Das (1993) } \\
\text { from }\end{array}$ & $\begin{array}{l}\text { Singh and } \\
\text { Kaur (2012) }\end{array}$ & Present study \\
\hline Locality & West Bengal & Punjab & Maharashtra \\
\hline
\end{tabular}

\section{CONCLUSION}

The present study indicates the presence of Thelohanellus parasites on gill surface and kidney of freshwater fishes mainly the Indian major carps in greater population which results in debilitary effect on the host. So in conclusion controlling measures should be taken to interrupt the steps of parasitic transmission from one host to other. Emphasis should be given to control the parasite with a view to increase the protein production together with the rapid growth of fishes. Therefore extensive study should be carried out on the Myxozoan parasites otherwise: the pathogenecity caused by them by damaging the tissue and decreasing the nutritional value, will lower the productivity of fish. The main principle of fish disease control should be based on all round prophylaxis and prevention is better than treatment approach as treatment in such water bodies become impractical and uneconomic.

\section{ACKNOWLEDGEMENTS}

We are thankful to Principal Dr. M. M. Sancheti, R.A. Arts, Shri M. K. Commerce and Shri S. R. Rathi Science Mahavidyalaya, Washim. (M.S.) for encouraging this research and providing highly equipped laboratory facility.

\section{REFERENCES}

Basu S., Modak B.K and Haldar D.P. (2006): Synopsis of the Indian species of the genus Thelohanellus Kudo, 1933 along with description of Thelohanellus disporomorphus sp.n . J. Parasit. Appl. Anim. Biol. ,15 ( 1Et2 ), 81 - 94 .

Cone, D.H. and Anderson R.C. (1977): Myxosporidan parasites of Pumpkinseed (Lepomis ibbosus L.) from Ontario. J. Parasit. 63: 657-666.

Hemananda T., Bandyopadhyay P. K., Mohilal N. and Mitra A. K. (2010): On the occurrence of a myxozoan parasite, Thelohanellus anilae sp. $n$. from a fresh water fish of India.

Kalavati, C. and N. C. Nandi (2007): Handbook of myxosporidean parasites of Indian fishes. Kolkata: Zoological Survey of India, $293 \mathrm{pp}$.

Kaur H., Dar S. A. and R. Singh (2013): One new and three already known Myxosporean parasites of Indian major carps in Punjab (India). Discovery publication. Species, vol.4: 17-24.

Kaur H, Dar S. A. and Katoch A. (2014a): Thelohanellus dykovi $s p$. (Myxozoa: Bivalvulidae), a pathogenic gill parasite in cultured Indian major carp, Labeo rohita (Hamilton 1822) in Punjab (India). Species, 10(23): 24-30.

Kaur H., Katoch A. and Gupta M. (2014b): Thelohanellus filli sp. n., a pathogenic Myxosporean infecting gills of cultured carp, Labeo rohita (Hamilton 1822) In Punjab, India Species, 2014, 10(23): 31-38.

Lom, J. and I. Dykova (2006): Myxozoan genera: definition and notes on taxonomy, life cycle terminology and pathogenic species. Folia Parasitologica 53: 1-36.

Pagarkar A. U. and Das M. K. (1993): Two new species of myxozoan, Thelohanellus caudatus $n$ sp. and Myxobolus serrata $n$. $s p$. from cultured carps. J.Inland Fish. Soc. India. 25 (1): 30-35.

Singh R. and Kaur H. (2012a): Two new Thelohanellus Kudo, 1933 (Myxozoa: Myxosporea: Bivalvulida) infecting fins of 
major carps in wetlands of Punjab. Trends in Parasitology Research,Vol.1, issue 3: 2319-3158.

Singh R. and Kaur H. (2012b): Thelohanellus (Myxozoa:Myxo sporea:Bivalvulida) infection in major carp fish from Punjab wetlands (India). Protistology 7 (3), 178-188.

Singh R. and Kaur H. (2012c): Two new and two already known species of genus Thelohanellus Kudo, 1933 (Myxozoa:
Myxosporea: Bivalvulida) infecting Indian major carp fishes in Punjab wetlands (India). J. Parasitol Disease.: 1-12.

Singh R. and Kaur H. (2012d): Myxosporean species of the genus Thelohanellus Kudo, 1933 (Myxozoa: Myxosporea: Bivalvulida) from freshwater fishes of Punjab wetlands, India. Protistology 7(4): 209-217. 